\title{
RNA-editing of the $5-\mathrm{HT}_{2 \mathrm{C}}$ receptor alters agonist-receptor-effector coupling specificity
}

\author{
${ }^{*, 1}$ Kelly A. Berg, ${ }^{1}$ Jodie D. Cropper, ${ }^{2,3}$ Colleen M. Niswender, ${ }^{2}$ Elaine Sanders-Bush, \\ ${ }^{2}$ Ronald B. Emeson \& ${ }^{1}$ William P. Clarke
}

${ }^{1}$ Department of Pharmacology, Mail Code 7764, University of Texas Health Science Center, San Antonio, Texas, TX 782293900, U.S.A. and ${ }^{2}$ Department of Pharmacology, Vanderbilt University, Nashville, Tennessee, TN 37232, U.S.A.

1 The serotonin ${ }_{2 \mathrm{C}}\left(5-\mathrm{HT}_{2 \mathrm{C}}\right)$ receptor couples to both phospholipase $\mathrm{C}$ (PLC)-inositol phosphate (IP) and phospholipase $\mathrm{A}_{2}$ (PLA $\mathrm{PL}_{2}$-arachidonic acid (AA) signalling cascades. Agonists can differentially activate these effectors (i.e. agonist-directed trafficking of receptor stimulus) perhaps due to agonist-specific receptor conformations which differentially couple to/activate transducer molecules (e.g. G proteins). Since editing of RNA transcripts of the human 5-HT $2 \mathrm{C}$ receptor leads to substitution of amino acids at positions 156,158 and 160 of the putative second intracellular loop, a region important for $\mathrm{G}$ protein coupling, we examined the capacity of agonists to activate both the PLC-IP and $\mathrm{PLA}_{2}$-AA pathways in CHO cells stably expressing two major, fully RNA-edited

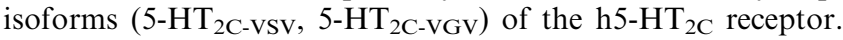

2 5-HT increased AA release and IP accumulation in both 5- $\mathrm{HT}_{2 \mathrm{C}-\mathrm{VSV}}$ and 5- $\mathrm{HT}_{2 \mathrm{C}-\mathrm{VGV}}$ expressing cells. As expected, the potency of 5-HT for both RNA-edited isoforms for both responses was 10 fold lower relative to that of the non-edited receptor $\left(5-\mathrm{HT}_{2 \mathrm{C}-\mathrm{INI}}\right)$ when receptors were expressed at similar levels.

3 Consistent with our previous report, the efficacy order of two 5-HT receptor agonists (TFMPP and bufotenin) was reversed for AA release and IP accumulation at the non-edited receptor thus demonstrating agonist trafficking of receptor stimulus. However, with the RNA-edited receptor isoforms there was no difference in the relative efficacies of TFMPP or bufotenin for AA release and IP accumulation suggesting that the capacity for $5-\mathrm{HT}_{2 \mathrm{C}}$ agonists to traffic receptor stimulus is lost as a result of RNA editing.

4 These results suggest an important role for the second intracellular loop in transmitting agonistspecific information to signalling molecules.

British Journal of Pharmacology (2001) 134, 386-392

Keywords: RNA-editing; G protein coupled receptors; serotonin receptors; efficacy; receptor-effector coupling; signal transduction, agonist trafficking

Abbreviations: AA, arachidonic acid; ADTRS, agonist-directed trafficking of receptor stimulus; CHO, Chinese hamster ovary; DOI, ( \pm )-1-(2,5-dimethoxy-4-iodophenyl)-2-aminopropane; $G$ protein, guanine nucleotide binding protein; HBSS, Hank's balanced salt solution; 5-HT, 5-hydroxytryptamine, serotonin; IP, inositol phosphates; LSD, lysergic acid diethylamide; PI, phosphatidylinositol; PLA2, phospholipase $\mathrm{A}_{2}$; PLC, phospholipase C; TFMPP, 3-trifluoromethylphenyl-piperazine; 7-TMS, seven transmembrane spanning

\section{Introduction}

The $\operatorname{serotonin}_{2 \mathrm{C}}\left(5-\mathrm{HT}_{2 \mathrm{C}}\right)$ receptor is a member of the $5-\mathrm{HT}_{2}$ seven transmembrane spanning (7-TMS) receptor family which characteristically activates second messenger signal transduction cascades via pertussis toxin insensitive $G$ proteins of the $\mathrm{G}_{\mathrm{q}}$ and possibly $\mathrm{G}_{12 / 13}$ families (Berg et al., 1999; Chang et al., 2000; Gohla et al., 1999). Activation of the $5-\mathrm{HT}_{2} \mathrm{C}$ receptor leads to both phospholipase $\mathrm{A}_{2}\left(\mathrm{PLA}_{2}\right)$ mediated arachidonic acid (AA) release and phospholipase $\mathrm{C}$ (PLC)-phosphatidylinositol (PI) hydrolysis in brain (Conn et al., 1986; Kaufman et al., 1995) and in heterologous expression systems (Berg et al., 1996; 1998). Recent studies have shown that the $5-\mathrm{HT}_{2 \mathrm{C}}$ receptor subtype is widely expressed at significant densities in numerous brain regions (Mengod et al., 1997) and there is increasing evidence that

*Author for correspondence; E-mail: berg@uthscsa.edu

${ }^{3}$ Current address: K-554 HSB, Department of Pharmacology, University of Washington, Seattle, WA 98195, U.S.A. this receptor plays a significant role in many physiological functions and behaviours, such as sleep, affective state, feeding behaviour and temperature regulation as well as being likely targets for hallucinogen drugs of abuse (for review see Roth et al., 1998).

The post-transcriptional process of editing of mRNA can generate unique isoforms of proteins in a cell and/or tissue specific manner (Simpson \& Emeson, 1996; Smith et al., 1997). Recently, mRNA transcripts of the rat and human (h) $5-\mathrm{HT}_{2 \mathrm{C}}$ receptor have been found to undergo adenosine-toinosine editing events at five sites which encompass amino acids 156-160 within the putative second intracellular loop of the encoded human receptor (Burns et al., 1997; Niswender et al., 1999). In human brain, the non-edited receptor contains the amino acids isoleucine, asparagine, and isoleucine (i.e., INI) at positions 156, 158 and 160, respectively, while two of the principal edited isoforms expressed have valine, serine and valine (i.e., VSV) or valine, 
glycine, and valine (i.e., VGV) corresponding to these amino acid positions (156, 158 and 160, respectively). In general, 5-HT has lower affinity for, and consequently is less potent at eliciting PI hydrolysis from, 5- $\mathrm{HT}_{2 \mathrm{C}-\mathrm{vSv}}$ or $5-\mathrm{HT}_{2 \mathrm{C}-\mathrm{VGV}}$ receptor isoforms in comparison with the non-edited 5- $\mathrm{HT}_{2 \mathrm{C}-\mathrm{INI}}$ receptor (Burns et al., 1997; Fitzgerald et al., 1999; Niswender et al., 1999). Further, guanine nucleotide-sensitive, high affinity binding is reduced (Fitzgerald et al., 1999; Herrick-Davis et al., 1999; Niswender et al., 1999) as is ligand-independent (constitutive) receptor activity (Herrick-Davis et al., 1999; Niswender et al., 1999) with the 5-HT $2 \mathrm{C}-\mathrm{vSV}$ or $5-\mathrm{HT}_{2 \mathrm{C}-\mathrm{VGV}}$ isoforms. Since the second intracellular loop of 7-TMS receptors is known to play a role in receptor-G protein coupling (Gudermann et al., 1997), these data suggest that RNA-edited 5- $\mathrm{HT}_{2 \mathrm{C}}$ receptor isoforms have reduced $\mathrm{G}$ protein-coupling efficiency.

Recently it has been suggested that 7-TMS receptor agonists may have the capacity to promote unique receptor conformations which can differentially couple to/activate each of multiple signalling cascades coupled to a single receptor. This hypothesis has been termed 'agonist-directed trafficking of receptor stimulus' (ADTRS) (Berg et al., 1998; Clarke \& Bond, 1998; Kenakin, 1995), because agonists can direct (traffic) the receptor stimulus differentially to individual signalling cascades. Thus, in contrast to the doctrine of traditional receptor theory (Furchgott, 1966), within the framework of ADTRS agonist intrinsic efficacy is effector pathway-dependent. Support for the ADTRS hypothesis has stemmed from studies in which reversal of agonist potency order (Robb et al., 1994; Spengler et al., 1993) and differences in agonist relative efficacy (Berg et al., 1998; Brink et al., 2000; Cordeaux et al., 2000) have been observed. For the $5-\mathrm{HT}_{2 \mathrm{C}}$ (and $5-\mathrm{HT}_{2 \mathrm{~A}}$ ) receptor system, using an unambiguous measure of agonist efficacy (maximal response to partial agonists), we have found that agonist relative efficacy differs depending upon whether PLC or PLA2 activity is measured and that agonist efficacy order also is responsedependent (Berg et al., 1998), providing strong support for ADTRS. Although the mechanism by which agonists differentially activate effector pathways has not been established, the currently favoured hypothesis for this action is that agonistspecific receptor conformations differentially couple to and/or activate transducer molecules, such as $\mathrm{G}$ proteins.

The amino acid changes in the $5-\mathrm{HT}_{2 \mathrm{C}}$ receptor as a result of editing occur in a region of the receptor known to participate in $\mathrm{G}$ protein coupling, however to date, the effect of RNA editing of the $5-\mathrm{HT}_{2 \mathrm{C}}$ receptor on signal transduction has been studied only for the PLC-PI effector system. The purpose of this study was to investigate the capacity of the fully RNA-edited h5$\mathrm{HT}_{2 \mathrm{C}}$ receptor isoforms $\left(5-\mathrm{HT}_{2 \mathrm{C}-\mathrm{VSV}}\right.$ and $\left.5-\mathrm{HT}_{2 \mathrm{C}-\mathrm{VGV}}\right)$ to activate the PLA2-AA effector system as well as the PLC-PI system. Additionally, we examined the impact of $\mathrm{h} 5-\mathrm{HT}_{2 \mathrm{C}}$ receptor RNA-editing on the capacity of agonists to differentially activate the PLC-PI versus PLA2-AA pathways (i.e., agonist-directed trafficking of receptor stimulus).

\section{Methods}

\section{Materials}

The following materials were purchased from commercial sources: $\left[{ }^{3} \mathrm{H}\right]-m y o$-inositol, $\left[{ }^{14} \mathrm{C}\right]$-arachidonic acid were pur- chased from New England Nuclear (Boston, MA, U.S.A.). 5HT $\mathrm{HCl},( \pm)$-2,5-dimethoxy-4-iodoamphetamine hydrobromide (DOI), lysergic acid diethylamide (LSD), bufotenin, quipazine maleate, 3-trifluoromethylphenyl-piperazine (TFMPP) were purchased from Research Biochemicals, Inc (Natick, MA, U.S.A.). Foetal bovine serum was from Gemini Bioproducts (Calabasas, CA, U.S.A.). All other tissue culture reagents were purchased from GIBCO (Grand Island, NY, U.S.A.). All other drugs and chemicals (reagent grade) were purchased from Sigma Chemical Co. (St. Louis, MO, U.S.A.).

\section{Transfection}

Stable co-transfection of CHO-K1 cells was performed in $35 \mathrm{~mm}$ dishes using lipofectamine (15 $\mu \mathrm{l}$ per well) and the mammalian expression vector pCMVII encoding either non-

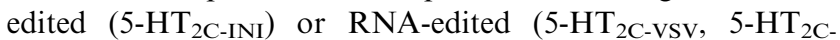
vGV) $\mathrm{h} 5-\mathrm{HT}_{2 \mathrm{C}}$ receptors $(2 \mu \mathrm{g}$ DNA) with $0.2 \mu \mathrm{g}$ of the expression vector, pZeoSV (Invitrogen), encoding zeocin resistance. For some experiments, cDNA inserts encoding $5-\mathrm{HT}_{2 \mathrm{C}-\mathrm{VSV}}$ and $5-\mathrm{HT}_{2 \mathrm{C}-\mathrm{vGV}}$ isoforms were cloned into the $k p n \mathrm{I}$ site of pZeoSV and expressed stably. Approximately 30-40 zeocin resistant colonies were isolated and screened for each construct. Stable clones were selected for their resistance to zeocin $\left(250 \mu \mathrm{g} \mathrm{ml}^{-1}\right)$, their ability to bind $\left[{ }^{3} \mathrm{H}\right]$ mesulergine and the ability to release AA and/or accumulate inositol phosphates (IP) in response to 5-HT, as described below.

\section{Cell culture}

CHO-INI, CHO-VSV and CHO-VGV cell lines are CHO-K1 cells which stably express non-edited $\left(5-\mathrm{HT}_{2 \mathrm{C}-\mathrm{INI}}\right)$ or RNAedited (5- $\mathrm{HT}_{2 \mathrm{C}-\mathrm{VSv}}, 5-\mathrm{HT}_{2 \mathrm{C}-\mathrm{VGV}}$ ) human $5-\mathrm{HT}_{2 \mathrm{C}}$ receptors, respectively. Cells were maintained in alpha-MEM supplemented with 5\% FBS and $100 \mu \mathrm{g} \mathrm{ml}^{-1}$ zeocin. For all experiments, cells were seeded into 12 or 24 well tissue culture vessels for functional studies or $15 \mathrm{~cm}$ dishes for radioligand binding studies at a density of $4 \times 10^{4}$ cells per $\mathrm{cm}^{2}$. Following a $24 \mathrm{~h}$ plating period, cells were washed with Hank's balanced salt solution (HBSS) and placed into D-MEM/F12 [1:1] with $5 \mu \mathrm{g} \mathrm{ml}^{-1}$ insulin, $5 \mu \mathrm{g} \mathrm{ml}^{-1}$ transferrin, $30 \mathrm{nM}$ selenium, $20 \mathrm{nM}$ progesterone and $100 \mu \mathrm{M}$ putrescine (serumfree media) and cultured for an additional $24 \mathrm{~h}$ prior to experimentation. Because some of the agonists used in this study (e.g., LSD, TFMPP) have some affinity for the $5-\mathrm{HT}_{1 \mathrm{~B}}$ receptor which is naturally expressed in CHO-K1 cells (Berg et al., 1994; Giles et al., 1996), all functional experiments were done in cells previously treated with pertussis toxin $\left(24 \mathrm{~h}, 50 \mathrm{ng} \mathrm{ml}^{-1}\right)$ during the serum-free culture period.

\section{Radioligand binding}

Saturation binding assays using $\left[{ }^{3} \mathrm{H}\right]$-mesulergine in cell membrane preparations (50 $\mu \mathrm{g}$ protein per tube) were done using 15 concentrations of radioligand in duplicate over a 3log unit range as previously described (Berg et al., 1994). Incubations were carried out for $1 \mathrm{~h}$ at $37^{\circ} \mathrm{C}$ followed by rapid filtration with $0.3 \%$ polyethyleneamine coated filters using a Brandel cell harvester. Non-specific binding was determined in the presence of $1 \mu \mathrm{M}$ mianserin. 
Competition binding assays were done with cell (CHOVSV; $2300 \mathrm{fmol} \mathrm{mg}^{-1}$ protein) membrane preparations (50 $\mu \mathrm{g}$ protein per tube) using half-log unit concentrations of the competing ligand over a range from $1 \times 10^{-10} \mathrm{M}$ to $1 \times 10^{-3} \mathrm{M}$ in the presence of $\left[{ }^{3} \mathrm{H}\right]$-mesulergine $(1 \mathrm{nM})$. Incubations were carried out for $1 \mathrm{~h}$ at $37^{\circ} \mathrm{C}$ followed by rapid filtration with $0.3 \%$ polyethyleneamine coated filters using a Brandel cell harvester.

\section{IP accumulation and $A A$ release measurements}

Cells were labelled with $1 \mu \mathrm{Ci} \mathrm{m}^{-1}\left[{ }^{3} \mathrm{H}\right]$-myo-inositol in serum free medium for $24 \mathrm{~h}$ and with $0.1 \mu \mathrm{Ci} \mathrm{ml}^{-1}\left[{ }^{3} \mathrm{H}\right]-$ arachidonic acid for $4 \mathrm{~h}$ at $37^{\circ} \mathrm{C}$ prior to experiments. Measurements of total $\left[{ }^{3} \mathrm{H}\right]-\mathrm{IP}$ accumulation were made from the same multiwell (simultaneously) as $\left[{ }^{3} \mathrm{H}\right]-\mathrm{AA}$ release measurements as described previously (Berg et al., 1998).

\section{Assessment of agonist-directed trafficking of receptor stimulus (ADTRS)}

To assess the capacity of agonists to differentially activate the PLC-IP $v s$ the PLA2-AA signalling pathways, relative efficacies of the test agonists were calculated for each response using the ratio of the response to maximal concentrations of the test agonist (at least $100 \times \mathrm{Ki}$ to produce full receptor occupancy) to that of the reference agonist 5-HT (i.e. intrinsic activity), as we have done before (Berg et al., 1998). Since all of the test ligands used in this study were partial agonists, the intrinsic activity of the ligands provides an unambiguous measure of relative efficacy (Kenakin, 1997). Traditional receptor theory necessitates that agonist relative efficacies must be independent of the response measured (Furchgott, 1966; Kenakin, 1997) and therefore the relative efficacies of the test ligands should not be different between responses. Consequently, a difference in the relative efficacy of an agonist determined from measurement of AA release or IP accumulation under identical conditions (see above) is interpreted as support for ADTRS. Although data demonstrating reversal of potency order of agonists for different responses (Robb et al., 1994; Spengler et al., 1993) has been interpreted as support for ADTRS (Kenakin, 1995), the use of potency measurements to assess agonist efficacy is potentially confounded, since potency of full (but not partial) agonists is determined by affinity as well as efficacy (see Kenakin, 1995).

\section{Data analysis}

For saturation binding experiments, data were fit with nonlinear regression to the model:

$$
B=\frac{B_{\max }}{1+\left(\frac{K_{d}}{[D]}\right)^{n}}+m \bullet D
$$

where $\mathrm{B}$ is the measured amount of radioligand bound (fmol $\mathrm{mg}^{-1}$ protein) in the presence of various concentrations of radioligand [D], $B_{\max }$ is the maximal amount bound, $K_{d}$ is the concentration producing half-maximal binding, $\mathrm{n}$ is the slope factor, and $\mathrm{m}$ is the slope of the linear regression line for 'non-specific' binding.
$\mathrm{IC}_{50}$ values were derived from non-linear regression analysis of competition binding data using the program Prism 3.0 for Macintosh (Graphpad). Data were fit with nonlinear regression analysis to one-site and two-site models and the best fit determined with an F-test by Prism software. The competition curves for all of the test ligands used were best fit with a one-site model. $K_{i}$ values were calculated from $\mathrm{IC}_{50}$ values using the transformation of Cheng-Prusoff (Cheng \& Prusoff, 1973).

Concentration response data were fit with nonlinear regression to the model:

$$
R=\frac{R_{\max }}{1+\left(\frac{E C_{50}}{[A]}\right)^{n}}
$$

where $\mathrm{R}$ is the measured response at a given agonist concentration (A), $\mathrm{R}_{\max }=$ maximal response, $\mathrm{EC}_{50}=$ the concentration of agonist producing half-maximal response, and $n=$ slope index.

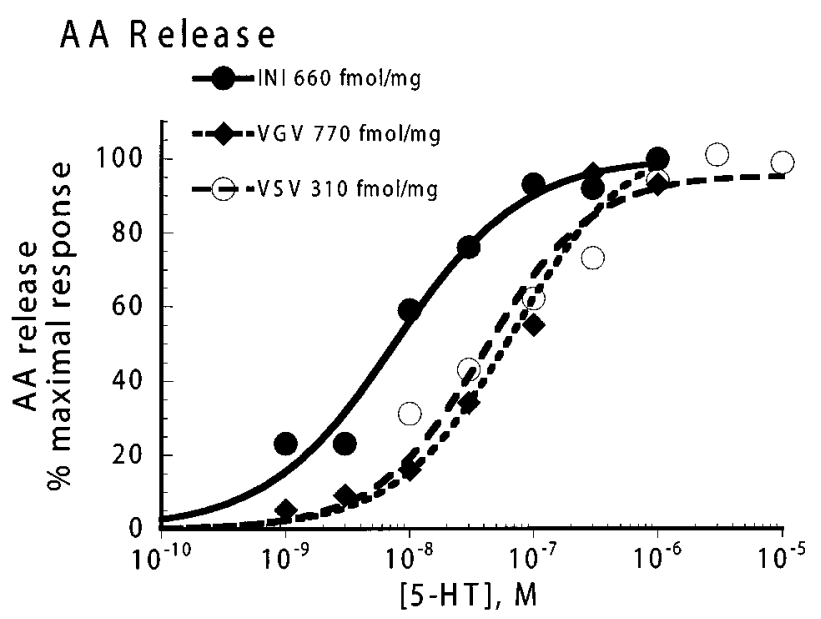

\section{IP Accumulation}

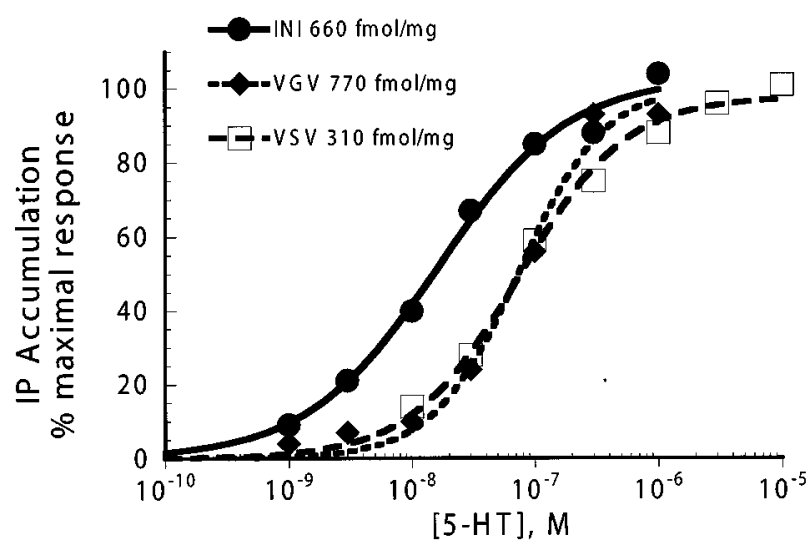

Figure 1 Comparison of concentration response curves to 5-HT between non-edited (5- $\left.\mathrm{HT}_{2 \mathrm{C}-\mathrm{INI}}\right)$ and RNA-edited $\left(5-\mathrm{HT}_{2 \mathrm{C}-\mathrm{VSV}}\right.$ and $\left.5-\mathrm{HT}_{2 \mathrm{C}-\mathrm{VGV}}\right) 5-\mathrm{HT}_{2 \mathrm{C}}$ receptor isoforms. CHO cells expressing stably the $5-\mathrm{HT}_{2 \mathrm{C}-\mathrm{INI}}, 5-\mathrm{HT}_{2 \mathrm{C}-\mathrm{VSV}}$ or $5-\mathrm{HT}_{2 \mathrm{C}-\mathrm{VGV}}$ receptor isoforms were incubated with various concentrations of 5-HT for $10 \mathrm{~min}$ followed by measurement of IP accumulation or AA release simultaneously from the same multiwell. Data shown are normalized to the per cent of $E_{\max }$ from each individual experiment and represent the mean of 4-5 experiments measured in triplicate. Individual concentration curves were fit to the logistic equation 2 described in Methods to determine $\mathrm{E}_{\max }$ and $\mathrm{EC}_{50}$ values (provided in Table 1). 
The Student $t$-test (paired) was used for statistical comparisons. Asterisks $(*)$ denote $P$ values $<0.05$.

\section{Results}

5-HT-mediated AA release and IP accumulation were measured simultaneously from the same cells expressing stably either the non-edited $\left(5-\mathrm{HT}_{2 \mathrm{C}-\mathrm{INI}}\right)$ or RNA-edited (5$\mathrm{HT}_{2 \mathrm{C}-\mathrm{VSV}}$ or $\left.5-\mathrm{HT}_{2 \mathrm{C}-\mathrm{VGV}}\right)$ receptors. As shown in Figure 1 and summarized in Table 1, 5-HT produced a concentrationdependent increase in both AA release and IP accumulation from each receptor isoform. For each receptor isoform the potency $\left(\mathrm{EC}_{50}\right)$ of 5-HT for IP accumulation was not different from that for AA release, however the potency for 5-HT at the edited isoforms was approximately 10 fold less than that for the non-edited receptor.

The relative efficacy of a series of partial agonists (at least $100 \times K_{i}$; see Table 2), with respect to 5 -HT, was measured for the $5-\mathrm{HT}_{2 \mathrm{C}-\mathrm{vsv}}$ receptor stably expressed at moderate levels
(310 $\mathrm{fmol} \mathrm{mg}^{-1}$ protein). In contrast to results obtained with the non-edited 5- $\mathrm{HT}_{2 \mathrm{C}}$ receptor (see Berg et al., 1998, and Figure $3 \mathrm{~B}$ ), agonist relative efficacy at the $5-\mathrm{HT}_{2 \mathrm{C}-\mathrm{vsv}}$ receptor was not different for IP accumulation and AA release (Table 2 ). Because the intrinsic activity of LSD was very low, the ability of LSD to elicit AA release and IP accumulation was measured in two additional clones where the 5- $\mathrm{HT}_{2 \mathrm{C}-\mathrm{vSv}}$ receptor isoform was overexpressed $\left(2300 \mathrm{fmol} \mathrm{mg}^{-1}\right.$ and $\left.7600 \mathrm{fmol} \mathrm{mg}^{-1}\right)$. As expected due to the increased receptor expression, the response to LSD was enhanced in these clones and therefore more accurately measured. Figure 2 shows that the relative efficacy of LSD on AA release was not different from that for IP accumulation in either clone.

ADTRS also did not occur with the 5- $\mathrm{HT}_{2 \mathrm{C}-\mathrm{VGV}}$ receptor isoforms (Figure 3). As we have shown previously (Berg et al., 1998), with the non-edited receptor $\left(5-\mathrm{HT}_{2 \mathrm{C}-\mathrm{INI}}\right)$, the relative efficacy of bufotenin and of LSD was greater for AA release than for IP accumulation, whereas the reverse was true for TFMPP (i.e. agonist efficacy order was reversed; Figure $3 \mathrm{~B})$. However, in cells stably expressing the $5-\mathrm{HT}_{2 \mathrm{C}}$ -

Table 1 Receptor binding and functional response parameters in $\mathrm{CHO}$ cells expressing non-edited (5-HT $2 \mathrm{C}$-INI) or edited (5-HT $2 \mathrm{C}-\mathrm{CVSV}$ and $5-\mathrm{HT}_{2 \mathrm{C}-\mathrm{VGV})}$ receptor

\begin{tabular}{|c|c|c|c|c|c|c|}
\hline & \multicolumn{2}{|c|}{$\left[{ }^{3} \mathrm{H}\right]$-mesulergine binding } & \multicolumn{2}{|c|}{ AA release } & \multicolumn{2}{|c|}{ IP accumulation } \\
\hline & $\begin{array}{c}B_{\max } \\
\text { (fmol mg }{ }^{-1} \text { protein) }\end{array}$ & $\begin{array}{c}K d \\
(\mathrm{nM})\end{array}$ & $\begin{array}{c}E_{\max } \\
\text { (\% above basal) }\end{array}$ & $p E C_{50}$ & $\begin{array}{c}E_{\max } \\
\text { (\% above basal) }\end{array}$ & $\begin{array}{c}p E C_{50} \\
(15 \mathrm{nM})\end{array}$ \\
\hline \multirow[t]{2}{*}{ INI } & 660 & 0.62 & $91 \pm 10$ & $\begin{array}{c}814 \pm 0.06 \\
(7 \mathrm{nM})\end{array}$ & $259 \pm 42$ & $7.82 \pm 0.13$ \\
\hline & 310 & 0.53 & $75 \pm 13$ & $\begin{array}{l}7.17 \pm 0.17^{*} \\
(68 \mathrm{~nm})\end{array}$ & $228 \pm 52$ & $\begin{array}{l}7.08 \pm 0.18^{*} \\
(83 \mathrm{nM})\end{array}$ \\
\hline \multirow[t]{2}{*}{ VSV } & 2300 & 0.92 & $143 \pm 26$ & $\begin{array}{l}7.66 \pm 0.30 \\
(21 \mathrm{~nm})\end{array}$ & $433 \pm 92$ & $\begin{array}{c}7.62 \pm 0.13 \\
(24 \mathrm{nM})\end{array}$ \\
\hline & 7600 & 0.62 & $136 \pm 30$ & $\begin{array}{c}7.74 \pm 0.12 \\
(18 \mathrm{nM})\end{array}$ & $584 \pm 95^{*}$ & $\begin{array}{c}7.98 \pm 0.12 \\
(10 \mathrm{nM})\end{array}$ \\
\hline VGV & 770 & 0.72 & $99 \pm 7$ & $\begin{array}{l}7.10 \pm 0.25^{*} \\
(79 \mathrm{nM})\end{array}$ & $177 \pm 40$ & $\begin{array}{c}6.91 \pm 0.18^{*} \\
(123 \mathrm{nM})\end{array}$ \\
\hline
\end{tabular}

Saturation binding isotherms were analysed using equation 1 in Methods to determine the $\mathrm{B}_{\max }$ and $\mathrm{K}_{\mathrm{D}}$ for $\left[{ }^{3} \mathrm{H}\right.$ ]-mesulergine. Binding data represent the mean of two experiments. Complete concentration response curves to 5-HT were fit to a logistic equation (equation 2) to determine $\mathrm{E}_{\max }$ and $\mathrm{EC}_{50}$ parameters for $\mathrm{AA}$ release and IP accumulation (measured simultaneously). Functional data shown represent the mean \pm s.e.mean of $4-5$ experiments. INI, VSV and VGV denote the 5-HT $2 \mathrm{C}-\mathrm{INI}, 5-\mathrm{HT}_{2 \mathrm{C}-\mathrm{VSV}}$ and 5 - $\mathrm{HT}_{2 \mathrm{C}-\mathrm{VGV}}$ receptor isoforms, respectively. ${ }^{*}$ Denotes statistical significance $(P<0.05)$ from 5 -HT $2 \mathrm{C}$-INI isoform.

Table 2 Relative efficacies of various $5-\mathrm{HT}_{2 \mathrm{C}}$ receptor agonists

\begin{tabular}{|c|c|c|c|c|}
\hline Drug & $p K_{i}$ & Concentration (maximal) & \multicolumn{2}{|c|}{$\begin{array}{c}\text { Relative efficacy } \\
E_{\max } \text { drug } / E_{\max } 5-H T\end{array}$} \\
\hline Bufotenin & $\begin{array}{l}7.11 \pm 0.13 \\
(78 \mathrm{nM})\end{array}$ & $30 \mu \mathrm{M}$ & $0.66 \pm 0.09$ & $0.65 \pm 0.05$ \\
\hline$( \pm)-\mathrm{DOI}$ & $\begin{array}{l}7.65 \pm 0.17 \\
(22 \mathrm{nM})\end{array}$ & $30 \mu \mathrm{M}$ & $0.57 \pm 0.08$ & $0.53 \pm 0.05$ \\
\hline d-LSD & n.d.* & $1 \mu \mathrm{M}$ & $0.23 \pm 0.08$ & $0.07 \pm 0.02$ \\
\hline TFMPP & $\begin{array}{l}7.26 \pm 0.05 \\
(55 \mathrm{nM})\end{array}$ & $30 \mu \mathrm{M}$ & $0.57 \pm 0.06$ & $0.61 \pm 0.10$ \\
\hline Quipazine & $\begin{array}{l}6.43 \pm 0.03 \\
(372 \mathrm{nM})\end{array}$ & $60 \mu \mathrm{M}$ & $0.47 \pm 0.08$ & $0.58 \pm 0.09$ \\
\hline
\end{tabular}

To determine relative efficacy, cells expressing the $5-\mathrm{HT}_{2 \mathrm{C}-\mathrm{vsv}}$ receptor isoform $\left(310 \mathrm{fmol}^{\mathrm{mg}}{ }^{-1}\right) \mathrm{were}^{\mathrm{incubated}}$ with concentrations of agonists to produce maximal receptor occupancy (at least $100 \times K_{i}$ ) for 10 min followed by measurement of AA release and IP accumulation, simultaneously, from the same multiwell. Data were normalized to the response to maximal 5-HT (3 $\mu \mathrm{M})$ determined in the same experiment and represent the mean \pm s.e.mean of 5-6 experiments measured in triplicate. 5-HT-mediated responses were $68-13 \%$ above basal (AA release, $n=6$ ) and $226-37 \%$ above basal (IP accumulation, $n=6$ ). $K_{i}$ values were calculated from competition binding experiments using $\left[{ }^{3} \mathrm{H}\right]$-mesulergine. All of the data were best fit with a one-site competition binding model. n.d. $=$ not determined. ${ }^{*}$ The $K_{i}$ for $\mathrm{LSD}$ at the $5-\mathrm{HT}_{2 \mathrm{C}-\mathrm{vSv}}$ receptor has been reported to be $84 \mathrm{~nm}$ (Fitzgerald et al., 1999 ). 


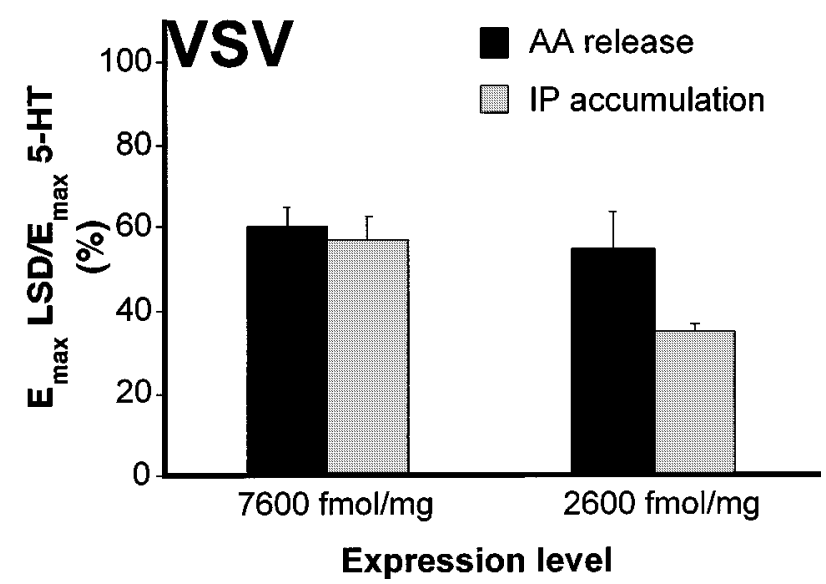

Figure 2 Relative efficacy of LSD for AA release and IP accumulation in cells expressing the 5 - $\mathrm{HT}_{2 \mathrm{C} \text {-vsv }}$ isoform at high densities. Cells were incubated with $300 \mathrm{~nm}$ LSD (maximal concentration) for $10 \mathrm{~min}$ followed by simultaneous measurement of AA release or IP accumulation. Bars show the intrinsic activity of LSD, referenced to the maximal 5-HT response determined in the same experiment, and represent the mean \pm standard error of three experiments. 5-HT-mediated AA release was $70 \pm 7 \%$ and $85 \pm 7 \%$ and 5-HT-mediated IP accumulation was $293 \pm 33 \%$ and $429 \pm 40 \%$, for cells expressing 2300 and $7600 \mathrm{fmol} \mathrm{mg}^{-1}$, respectively.

VGV isoform, using two different clones, there was no difference in the relative efficacies for bufotenin or TFMPP. Interestingly, LSD failed to elicit either AA release or IP accumulation in $\mathrm{CHO}$ cells expressing the $5-\mathrm{HT}_{2 \mathrm{C}-\mathrm{VGV}}$ isoform.

\section{Discussion}

RNA-edited 5-HT $\mathrm{H}_{2 \mathrm{C}}$ receptor isoforms, 5-HT $2 \mathrm{C-VSV}$ and 5-HT $2 \mathrm{C}-V G V$, couple to both $\mathrm{PLA} \mathrm{A}_{2}$ and PLC

Amino acid changes in the second intracellular loop of 7TMS receptors might be expected to alter coupling to or activation of $\mathrm{G}$ proteins (Gudermann et al., 1997) or other transducer molecules which may interact with the receptor in this region (Hall et al., 1999). The 5- $\mathrm{HT}_{2 \mathrm{C}-\mathrm{VGV}}$ and 5$\mathrm{HT}_{2 \mathrm{C}-\mathrm{VSV}}$ isoforms of the $5-\mathrm{HT}_{2 \mathrm{C}}$ receptor have different amino acids in the second intracellular loop from the 5$\mathrm{HT}_{2 \mathrm{C} \text {-INI }}$ (non-edited) receptor and these edited receptor isoforms have reduced capacity to signal to the PLC-PI effector pathway (Burns et al., 1997; Niswender et al., 1999; Fitzgerald et al., 1999). In addition to the PLC-PI effector pathway, the 5- $\mathrm{HT}_{2 \mathrm{C}}$ receptor also couples to the PLA2AA signalling cascade, however the effect of RNA editing on the ability of the $5-\mathrm{HT}_{2 \mathrm{C}}$ receptor to activate PLA2 signalling has not been studied. We found that 5-HT increased both AA release as well as IP accumulation (measured simultaneously from the same cells) from each edited receptor isoform. For each receptor isoform (edited and non-edited) the potency of 5-HT did not differ between effector pathways as might be expected since both responses stem from activation of the same receptor. As reported previously (Burns et al., 1997; Niswender et al., 1999; Fitzgerald et al., 1999), the potency for 5-HT to elicit IP accumulation at the edited receptors $\left(5-\mathrm{HT}_{2 \mathrm{C}-\mathrm{vSV}}\right.$ or 5-
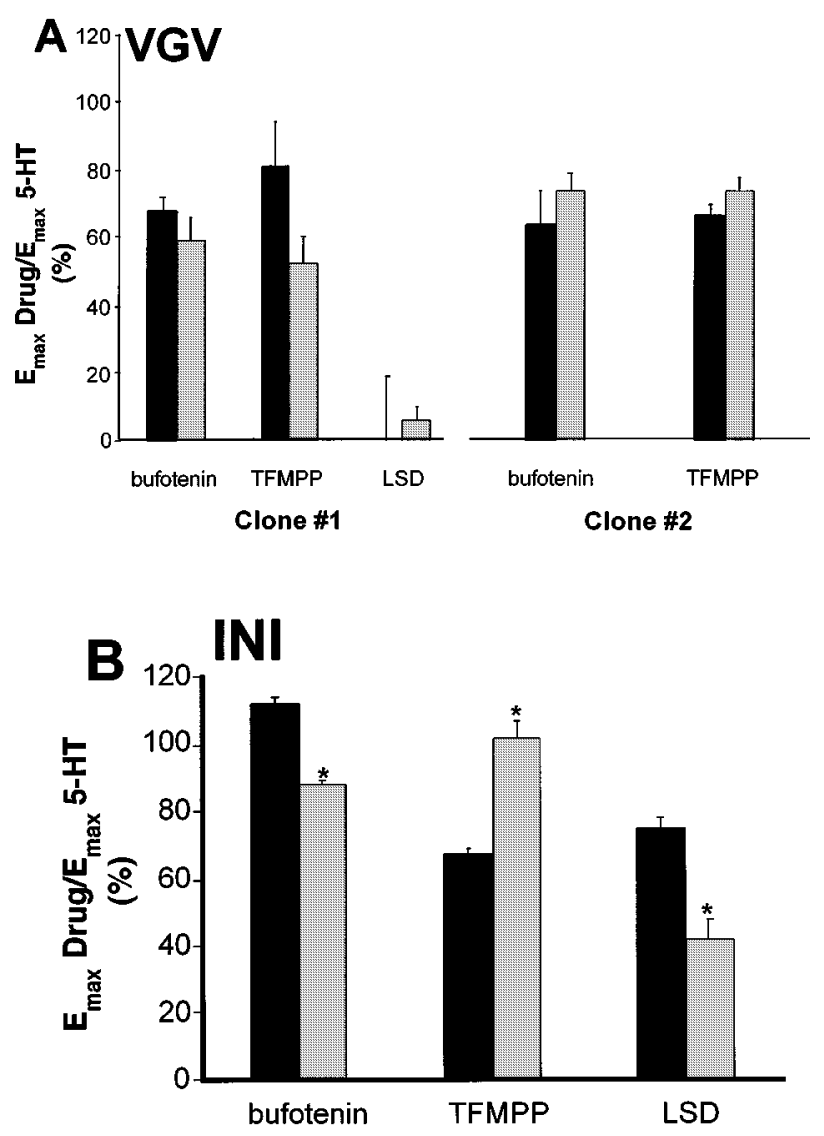

Figure 3 Comparison of relative efficacies of bufotenin, TFMPP and LSD between 5- $\mathrm{HT}_{2 \mathrm{C}-\mathrm{INI}}$ and $5-\mathrm{HT}_{2 \mathrm{C}-\mathrm{VGV}}$ receptor isoforms. Cells were incubated for $10 \mathrm{~min}$ with maximal concentrations of LSD (300 nM), bufotenin $\left(10 \mu \mathrm{M}\right.$ for 5 - $\mathrm{HT}_{2 \mathrm{C}-\mathrm{INI}}$ and $30 \mu \mathrm{M}$ for $5-\mathrm{HT}_{2 \mathrm{C}}$ VGV), TFMPP (10 $\mu \mathrm{M}$ for $5-\mathrm{HT}_{2 \mathrm{C}-\mathrm{INI}}$ and $30 \mu \mathrm{M}$ for $\left.5-\mathrm{HT}_{2 \mathrm{C}-\mathrm{VGV}}\right)$ or 5 -HT ( $1 \mu \mathrm{M}$ for $5-\mathrm{HT}_{2 \mathrm{C}-\mathrm{INI}}$ and $3 \mu \mathrm{M}$ for $\left.5-\mathrm{HT}_{2 \mathrm{C}-\mathrm{VGV}}\right)$. AA release and IP accumulation were measured simultaneously from the same multiwell. Data were normalized to the 5-HT response determined in the same experiment and represent the mean \pm s.e.mean of 3-6 experiments. 5-HT-mediated responses for the 5 - $\mathrm{HT}_{2 \mathrm{C}-\mathrm{INI}}$ isoform were $85 \pm 13 \%$ and $285 \pm 47 \%$, for the $5-\mathrm{HT}_{2 \mathrm{C}-\mathrm{VGV}}$ clone $\# 1$, $86 \pm 15 \%$ and $169 \pm 10 \%$ and for $5-\mathrm{HT}_{2 \mathrm{C}-\mathrm{VGV}}$ clone $\# 2,47 \pm 6 \%$ and $189 \pm 4 \%$, AA release and IP accumulation, respectively. *Denotes statistical significance between agonist-mediated AA release and IP accumulation.

$\mathrm{HT}_{2 \mathrm{C}-\mathrm{VGV}}$ ) was less than that for the non-edited receptor (5- $\left.\mathrm{HT}_{2 \mathrm{C}-\mathrm{INI}}\right)$ when expressed at similar densities. Similarly, the potency for 5-HT to stimulate AA release was also less for the edited receptors. This result is consistent with the finding that affinity of $5-\mathrm{HT}$ for $5-\mathrm{HT}_{2 \mathrm{C}-\mathrm{VSV}}$ and $5-\mathrm{HT}_{2} \mathrm{C}$ $\mathrm{VGV}$ isoforms is reduced in comparison to that of nonedited 5-HT $2 \mathrm{C}-\mathrm{INI}$ receptors (Niswender et al., 1999; Fitzgerald et al., 1999; Herrick-Davis et al., 1999). The higher potency of 5-HT in the cell lines expressing the 5$\mathrm{HT}_{2 \mathrm{C}-\mathrm{vSv}}$ isoform at high levels is consistent with the presence of receptor reserve in these cells.

\section{Agonist-directed trafficking of receptor stimulus} (ADTRS) does not occur at the RNA-edited h5-HT ${ }_{2 C}$ receptor isoforms

Although traditional receptor theory allows for receptors to couple to multiple effector pathways, it does not accom- 
modate the capacity for agonists to differentially activate effectors. Within the context of traditional receptor theory, the intrinsic efficacy of agonists (and consequently agonist relative efficacy) must be independent of the response measured (Furchgott, 1966). Since potency of full agonists is, in part, influenced by efficacy, recent reports that the potency order of agonists differs depending upon the response measured (Robb et al., 1994; Spengler et al., 1993) suggested that agonist relative efficacy may, in fact, be dependent on response and prompted Kenakin to propose a new hypothesis he termed 'agonist-directed trafficking of receptor stimulus' (Kenakin, 1995). The main premise of this hypothesis is that agonists are able to promote the formation of agonist-specific receptor conformations and that these conformations have different capacities to activate effector pathways. Within this framework, agonist intrinsic efficacy would not be independent of the response measured. Although the ADTRS hypothesis, as formulated by Kenakin, does not presuppose a mechanism, the simplest way agonists could differentially activate effectors coupled to the same receptor is if agonist-specific conformations have different capacities to couple to or activate transducer molecules, such as $\mathrm{G}$ proteins.

Using an unambiguous measure of agonist relative efficacy (intrinsic activity of partial agonists), we recently found that for the unedited $5-\mathrm{HT}_{2 \mathrm{C}}$ receptor $\left(5-\mathrm{HT}_{2 \mathrm{C}-\mathrm{INI}}\right)$ agonist relative efficacy differed depending on whether AA release or IP accumulation was measured (Berg et al., 1998). Furthermore, for some agonists, efficacy order was reversed. Relative to 5-HT, DOI, bufotenin and LSD preferentially activated the PLA2-AA pathway, while quipazine and TFMPP favoured IP accumulation. In the present study using a different clonal cell line transfected with a different expression vector from those used in our original report, we replicated our original finding that not only was agonist relative efficacy different for different responses coupled to the non-edited $5-\mathrm{HT}_{2 \mathrm{C}}$ receptor, but efficacy order was reversed for bufotenin and TFMPP. This difference in agonist efficacy order is strong evidence in support of the ADTRS hypothesis.

Since the changes in amino acids produced as a result of RNA editing of the $5-\mathrm{HT}_{2 \mathrm{C}}$ receptor mRNA are in a region of the receptor which has been shown to be involved in signal transduction and $\mathrm{G}$ protein coupling for several 7-TMS receptors (Gudermann et al., 1997), we examined the ability of agonists to differentially activate PLC-IP versus PLA2-AA in cells expressing the $5-\mathrm{HT}_{2 \mathrm{C}-\mathrm{vSV}}$ or $5-\mathrm{HT}_{2 \mathrm{C}-\mathrm{VGV}}$ isoforms. Consistent with previous reports showing that LSD does not increase PLC activity in NIH-3T3 cells expressing the 5$\mathrm{HT}_{2 \mathrm{C}-\mathrm{VGV}}$ isoform (Backstrom et al., 1999; Fitzgerald et al., 1999), we also found that LSD did not elicit either AA release or IP accumulation in $\mathrm{CHO}$ cells with the $5-\mathrm{HT}_{2 \mathrm{C}-\mathrm{VGV}}$ receptor. In contrast to our results with the non-edited 5$\mathrm{HT}_{2 \mathrm{C}}$ receptor, we found that agonist relative efficacy was not different between responses for the edited receptors. These results suggest that agonists cannot differentially traffic receptor stimulus to each of the two effector pathways coupled to the receptor when amino acids are changed at positions 156, 158 and 160 in the second intracellular loop of the $5-\mathrm{HT}_{2 \mathrm{C}}$ receptor.

In conclusion, using an unambiguous measure of relative efficacy, we have shown that the relative efficacy for agonists to activate PLC-PI hydrolysis is not different from their relative efficacy to activate PLA2-AA release upon activation of the $5-\mathrm{HT}_{2 \mathrm{C}-\mathrm{VSV}}$ and $5-\mathrm{HT}_{2 \mathrm{C}-\mathrm{VGV}} \mathrm{RNA}$-edited isoforms of the $5-\mathrm{HT}_{2 \mathrm{C}}$ receptor. This is in contrast to the different relative efficacies and different efficacy order for agonists acting at the non-edited $\left(5-\mathrm{HT}_{2 \mathrm{C}-\mathrm{INI}}\right)$ receptor. The lack of effector pathway-dependence of agonist relative efficacy indicates that the potential for agonists to traffic receptor stimuli differentially to effector mechanisms is missing from the edited $5-\mathrm{HT}_{2 \mathrm{C}}$ receptor isoforms and suggests that the second intracellular loop may play an important role in transmitting agonist-specific information to signalling molecules. The currently favoured hypothesis for the mechanism of ADTRS is that agonists promote the formation of ligandspecific receptor conformations which have different capacities to couple to/activate signalling molecules (e.g., G proteins). The loss of ADTRS with RNA-edited receptor isoforms suggests either that the edited isoforms are not capable of adopting ligand-specific conformations or that the capacity of ligand-specific conformations to differentially interact with signalling molecules is impaired. The loss of spontaneous receptor activity as a result of RNA editing (Niswender et al., 1999; Herrick-Davis et al., 1999) may suggest that these isoforms are more restricted in the conformations they adopt and thus, perhaps, the ability of ligands to promote different receptor conformations is also impaired. However, since it has been shown that the coupling efficiency of edited isoforms to G proteins and to the PLC pathway is reduced (Niswender et al., 1999; Fitzgerald et al., 1999), it seems likely that changes in the ability of ligandspecific receptor conformations to differentially interact with signalling molecules is the most likely explanation for the lack of agonist-directed trafficking. Support for this hypothesis must await identification of the transducing molecule(s) that couples the $5-\mathrm{HT}_{2 \mathrm{C}}$ receptor to PLA2.

This work was supported by United States Public Health Service Grants DA 09094 (K.A. Berg), GM 58652 (W.P. Clarke); MH 34005 (E. Sanders-Bush), NS 36891 (R.B. Emeson) and grants from the Pharmaceutical Research and Manufacturers of America Foundation (C.M. Niswender) and the Texas Advanced Research Program (3659-0044; W.P. Clarke, K.A. Berg). The authors would like to thank Drs David McLoughlin and Brian Stout for helpful comments and Blythe King and Bonnie Garcia for expert technical assistance.

\section{References}

BACKSTROM, J.R., CHANG, M.S., CHU, H., NISWENDER, C.M. \& SANDERS-BUSH, E. (1999). Agonist-directed signaling of serotonin 5-HT2C receptors: differences between serotonin and lysergic acid diethylamide (LSD). Neuropsychopharmacology, 21, $77 \mathrm{~S}-81 \mathrm{~S}$.

BERG, K.A., CLARKE, W.P., SAILSTAD, C., SALTZMAN, A. \& MAAYANI, S. (1994). Signal transduction differences between 5hydroxytryptamine type $2 \mathrm{~A}$ and type $2 \mathrm{C}$ receptor systems. Mol. Pharmacol., 46, 477-484. 
BERG, K.A., MAAYANI, S. \& CLARKE, W.P. (1996). 5-hydroxytryptamine $2 \mathrm{C}$ receptor activation inhibits 5 -hydroxytryptamine $1 \mathrm{~B}-$ like receptor function via arachidonic acid metabolism. Mol. Pharmacol., 50, $1017-1023$.

BERG, K.A., MAAYANI, S., GOLDFARB, J., SCARAMELLINI, C., LEFF, P. \& CLARKE, W.P. (1998). Effector pathway-dependent relative efficacy at serotonin type $2 \mathrm{~A}$ and $2 \mathrm{C}$ receptors: evidence for agonist-directed trafficking of receptor stimulus. Mol. Pharmacol., 54, 94-104.

BERG, K.A., STOUT, B.D., CROPPER, J.D., MAAYANI, S. \& CLARKE, W.P. (1999). Novel actions of inverse agonists on 5-HT2C receptor systems. Mol. Pharmacol., 55, 863-872.

BRINK, C.B., WADE, S.M. \& NEUBIG, R.R. (2000). Agonist-directed trafficking of porcine alpha( $2 \mathrm{~A})$-adrenergic receptor signaling in Chinese hamster ovary cells: 1 -isoproterenol selectively activates G(s). J. Pharmacol. Exp. Ther., 294, 539-547.

BURNS, C.M., CHU, H., RUETER, S.M., HUTCHINSON, L.K., CANTON, H., SANDERS-BUSH, E. \& EMESON, R.B. (1997). Regulation of serotonin-2C receptor G-protein coupling by RNA editing. Nature, 387, 303-308.

CHANG, M., ZHANG, L., TAM, J.P. \& SANDERS-BUSH, E. (2000). Dissecting $G$ protein-coupled receptor signaling pathways with membrane-permeable blocking peptides. Endogenous 5-HT(2C) receptors in choroid plexus epithelial cells. J. Biol. Chem., 275, $7021-7029$.

CHENG, Y. \& PRUSOFF, W.H. (1973). Relationship between the inhibition constant $(\mathrm{Ki})$ and the concentration of inhibitor which causes 50 per cent inhibition (I50) of an enzymatic reaction. Biochem. Pharmacol., 22, 3099-3108.

CLARKE, W.P. \& BOND, R.A. (1998). The elusive nature of intrinsic efficacy. Trends. Pharmacol. Sci., 19, 270-276.

CONN, P.J., SANDERS-BUSH, E., HOFFMAN, B.J. \& HARTIG, P.R. (1986). A unique serotonin receptor in choroid plexus is linked to phosphatidylinositol turnover. Proc. Natl. Acad. Sci. U.S.A., 83, $4086-4088$

CORDEAUX, Y., BRIDDON, S.J., MEGSON, A.E., MCDONNELL, J., DICKENSON, J.M. \& HILL, S.J. (2000). Influence of receptor number on functional responses elicited by agonists acting at the human adenosine $\mathrm{A}(1)$ receptor: evidence for signaling pathwaydependent changes in agonist potency and relative intrinsic activity. Mol. Pharmacol., 58, $1075-1084$.

FITZGERALD, L.W., IYER, G., CONKLIN, D.S., KRAUSE, C.M., MARSHALL, A., PATTERSON, J.P., TRAN, D.P., JONAK, G.J. \& HARTIG, P.R. (1999). Messenger RNA editing of the human serotonin 5-HT2C receptor. Neuropsychopharmacology, 21, $82 \mathrm{~S}-90 \mathrm{~S}$.

FURCHGOTT, R.F. (1966). The use of B-haloalkylamines in the differentiation of receptors and in the determination of dissociation constants of receptor-agonist complexes. In $A d$ vances in Drug Research., ed. Harper, N.J. \& Simmonds, A.B. pp. 21 -55. London: Academic Press.

GILES, H., LANSDELL, S.J., BOLOFO, M.L., WILSON, H.L. \& MARTIN, G.R. (1996). Characterization of a 5- $\mathrm{HT}_{1 \mathrm{~B}}$ receptor on $\mathrm{CHO}$ cells: functional responses in the absence of radioligand binding. Br. J. Pharmacol., 117, 1119-1126.
GOHLA, A., OFFERMANNS, S., WILKIE, T.M. \& SCHULTZ, G. (1999). Differential involvement of Galpha12 and Galpha13 in receptormediated stress fiber formation. J. Biol. Chem., 274, 1790117907

GUDERMANN, T., SCHONEBERG, T. \& SCHULTZ, G. (1997). Functional and structural complexity of signal transduction via G - protein-coupled receptors. Annu. Rev. Neurosci., 20, $399-$ 427.

HALL, R.A., PREMONT, R.T. \& LEFKOWITZ, R.J. (1999). Heptahelical receptor signaling: beyond the $\mathrm{G}$ protein paradigm. J. Cell. Biol., 145, $927-932$.

HERRICK-DAVIS, K., GRINDE, E \& NISWENDER, C.M (1999). Serotonin 5-HT2C receptor RNA editing alters receptor basal activity: implications for serotonergic signal transduction. $J$. Neurochem., 73, $1711-1717$.

KAUFMAN, M.J., HARTIG, P.R. \& HOFFMAN, B.J. (1995). Serotonin 5-HT2C receptor stimulates cyclic GMP formation in choroid plexus. J. Neurochem., 64, 199-205.

KENAKIN, T. (1995). Agonist-receptor efficacy II: agonist trafficking of receptor signals. Trends. Pharmacol. Sci., 16, 232-238.

KENAKIN, T. (1997). Pharmacologic analysis of drug-receptor interaction. 3rd edition. New York: Raven Press.

MENGOD, G., PALACIOS, J.M., WIEDERHOLD, K.H. \& HOYER, D. (1997). 5-hydroxytryptamine receptor histochemistry: Comparison of receptor mRNA distribution and radioligand autoradiography in the brain. In Serotonergic. Neurons and 5-HT Receptors in the CNS. ed. Baumgarten, H.G. \& Gothert, M. pp. 213-237. Berlin: Springer-Verlag.

NISWENDER, C.M., COPELAND, S.C., HERRICK-DAVIS, K., EMESON, R.B. \& SANDERS-BUSH, E. (1999). RNA editing of the human serotonin 5-hydroxytryptamine $2 \mathrm{C}$ receptor silences constitutive activity. J. Biol Chem., 274, 9472-9478.

ROBB, S., CHEEK, T.R., HANNAN, F.L., HALL, L.M., MIDGLEY, J.M \& EVANS, P.D. (1994). Agonist-specific coupling of a cloned Drosophila octopamine/tyramine receptor to multiple second messenger systems. EMBO J., 13, 1325-1330.

ROTH, B.L., WILLINS, D.L., KRISTIANSEN, K. \& KROEZE, W.K (1998). 5-Hydroxytryptamine2-family receptors (5-hydroxytryptamine2A, 5-hydroxytryptamine2B, 5-hydroxytryptamine2C): where structure meets function. Pharmacol. Ther., 79, 231-257.

SIMPSON, L. \& EMESON, R.B. (1996). RNA editing. Annu. Rev. Neurosci., 19, $27-52$.

SMITH, H.C., GOTT, J.M. \& HANSON, M.R. (1997). A guide to RNA editing. $R N A, \mathbf{3}, 1105-1123$.

SPENGler, D., WAEber, C., PANTAloni, C., HOlsboer, F., BOCKAERT, J., SEEBURG, P.H. \& JOURNOT, L. (1993). Differential signal transduction by five splice variants of the PACAP receptor. Nature, $\mathbf{3 6 5}, 170-175$.

(Received February 15, 2001 Revised June 11, 2001 Accepted June 25, 2001) 